\title{
影付け平面を用いた複合現実感における高速陰影表現手法
}

\section{Fast Shading and Shadowing of Virtual Objects Using Shadowing Planes in Mixed Reality}

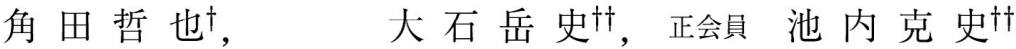

Tetsuya Kakuta ${ }^{\dagger}$, Takeshi Oishi ${ }^{\dagger \dagger}$ and Katsushi Tkeuchi ${ }^{\dagger \dagger}$

\begin{abstract}
We have developed a fast shading and shadowing method that uses the shadowing planes and the basis images in mixed reality (MR). The method is model-based and computable in real time by using a standard graphics processing unit (GPU) making it particularly effective when used with an outdoor MR application. To express the shadows of objects, we map the shadow images that are synthesized from the basis images rendered offline with the basis lights onto the shadowing planes, and we compute alpha blending with the objects. The shadowing planes are generated from convex hulls of objects. We obtain the radiance parameters of the real scene from an omnidirectional image and compute the linear sum of the radiance parameters and the basis images on the GPU. We applied this shadowing method to both an indoor and outdoor MR application and found it to be effective.
\end{abstract}

キーワード：複合現実感，拡張現実感，光学的整合性，影付け，ソフトシャドウ

\section{1. まえ がき}

近年，現実世界とコンピュータグラフィックス $(\mathrm{CG})$ によ って表現された仮想世界を融合する複合現実感 (MR: Mixed Reality）に関する研究が盛んに行われている ${ }^{1) \sim 3)}$. MR で は，ヘッドマウントデイスプレイ (HMD) 等の表示装置を 用いて，現実世界の撮影画像にCG を重ね合わせることに より，あたかもCGで描いた仮想物体が現実世界に出現し たかのように見せることが可能である，MRは，工業・教 育・医療・建築分野等への応用が期待されており，より現 実感の高い合成画像が求められるようになってきている.

MRに执いて仮想世界と実世界の違和感のない合成を行 うためには，仮想物体と実画像との間の光学的整合性を満 たすことが重要である ${ }^{4)}$.光学的整合性を実現するために は，仮想世界と実世界の色・明るさ・陰影等の条件を一致 させる必要がある.すなわち，ある特定の光源環境の下で， 仮想物体と実物体の表面における院（Shade）を一致させ るとともに，両者が光を遮ることによって互いに落とし合

2007 年 9 月 28 日受付, 2008 年 1 月 17 日再受付, 2008 年 2 月 20 日採録 †東京大学 大学院 学際情報学府 - 日本学術振興会特別研究員 DC ( 于 113-0033 文京区本郷 7-3-1, TEL 03-5841-5938) ††東京大学 大学院 情報学環

( $=113-0033$ 文京区本郷 7-3-1, TEL 03-5841-5938)

$\dagger$ Graduate School of Interdisciplinary Information Studies, The University of Tokyo, JSPS Researc Fellow

(7-3-1, Hongo, Bunkyo-ku, Tokyo 113-0033, Japan)

$\dagger \dagger$ Interfaculty Initiative in Information Studies, The University of Tokyo

(7-3-1, Hongo, Bunkyo-ku, Tokyo 113-0033, Japan)
う影（Shadow）を表現しなければならない。

従来より CG の分野では物体の陰影付けに関する研究が 盛んに行われている ${ }^{5) \sim 7)}$. しかし MRにおける除影付け は，CG における単純な陰影付けと異なり，1）実時間で 処理を行い，2）実世界の光源環境に対応し，3）実・仮 想物体相互の影付けを表現しなければならない，という課 題がある。

MRに扔ける光学的整合性の実現に関して，これまでに 多くの研究がなされている ${ }^{8)}$. 実世界の光源情報を取得す る方法としては，ビデオカメラを用いる方法 ${ }^{9110)}$, 鏡面球 を用いる方法 ${ }^{1112)}$ ，光センサを用いる手法 ${ }^{13)}$ ，物体の影 を分析する方法 ${ }^{14)}$ 等が提案されている.

また影付けに関しては, シャドウマップ法やシャドウボ リューム法を用いる手法 ${ }^{15) 16)}$ が提案されているが，これら は仮想物体のソフトシャドウを表現することができず，合 成画像の写実性にそしいという問題がある。一方，実世界 の高ダイナミックレンジ画像を用いて仮想物体を埋め込ん だシーンの大局照明を計算し，仮想物体のソフトシャドウ を生成する手法を提案されている ${ }^{11)}$. しかしこの手法は実 時間での処理が難しいという制約がある。一方，あらかじ め前処理で生成しておいた基礎画像を線形結合することに よって，仮想物体のソフトシャドウを高速に生成する手法 が提案されている ${ }^{917)}$ 。これらの手法は，前処理における 基礎画像のレンダリングにラジオシティ法等を利用し，写 実的な合成画像を生成することができる。しかし，カメラ の位置が固定された画像べースの于法であるため，ユーザ 


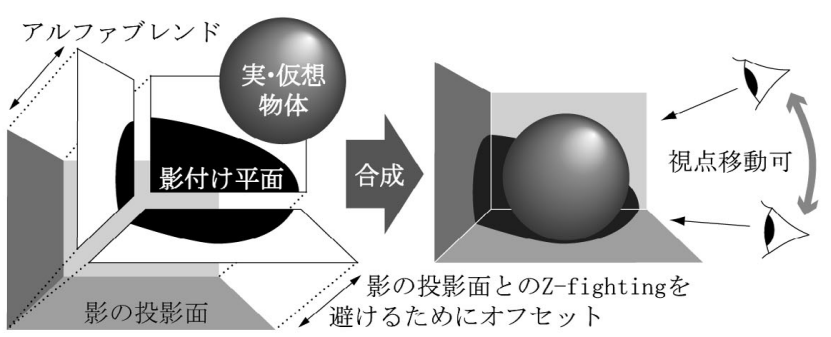

図 1 影付け平面を用いた影付け

Shadowing using shadowing planes.

は視点を変更することができない．

本稿では，MRに打ける光学的整合性問題を解決するた め, シーンの 3 次元モデル周辺に仮想的な平面状の物体 (以 下, 影付け平面と呼ぶ）を配置し, この平面群に対して物 体の影を表す画像をテクスチャマッピングすることによっ て，実光源環境に対応した物体のソフトシャドウを高速に 表現する手法を提案する。本手法は従来手法に比べて次の 二つの新規性がある.

・影付け平面によって視点変更が可能.

・GPUによる実時間処理が可能.

本手法は前処理段階で影付け平面をシーンに配置し, 実 光源環境を近似した基礎光源によって物体の影を生成して 基礎画像として蓄える. 逐次処理段階では, 魚眼レンズ付 きカメラを用いて取得した全方位画像から実世界の光源分 布を推定し, 基礎画像と放射輝度パラメー夕の線形和を求 めることによって任意の光源環境に対応した影画像を生成 する. 次に，図 1 に示すように，影画像を影付け平面にマッ ピングし，アルファブレンドすることによって物体表面の 影を表現する。本稿で提案する影付け手法は, 画像べース の従来手法917) と異なりモデルベースであるためユーザの 視点変更が可能である．また基礎画像の合成は単純な線形 結合演算であるため, GPU のシェーダ機能を用いて実時 間で行うことが可能である。 そのため本手法は, 従来手法 と比べて屋外などの光源環境が変化するアプリケーション に有効である。

以降, 第 2 章では提案手法の処理の流れについて概要を 述べる. 第 3 章では, 影付け平面の生成方法および GPU による基礎画像の合成とアルファブレンディングによる影 付け方法を説明する. 第 4 章では, 基礎光源および基礎画 像の生成方法, 実光源環境の取得と放射輝度パラメータの 計算方法について述べる. 第 5 章では, 室内・屋外環境に 捛ける提案手法を用いた実・仮想物体の合成実験の結果を 示す. 最後に第 6 章でまとめと今後の課題について述べる.

\section{2. 概 要}

提案手法の処理の流れを図 2 に示す.まず（a）前処理段 階で実・仮想物体の $3 \mathrm{D}$ モデルを分割し，各部分の凸包か ら影付け平面を生成する。次に（b）実光源環境を近似した 基礎光源を作成し，(c) 基礎光源を用いてシーンをレンダ

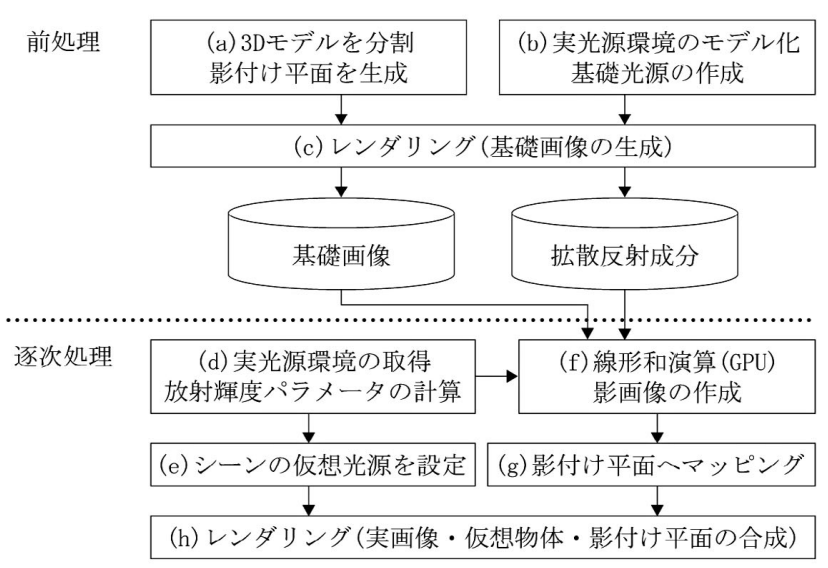

図 2 提案手法の処理の流れ

Flowchart of the proposed method.

リングする。そして影付け平面に落ちる物体の影を基礎画 像として蓄積する。

逐次処理では，まず（d）魚眼レンズ付ビデオカメラに より実光源環境を撮影し，放射輝度パラメー夕を計算する。 次に（e）仮想物体のシェーディングを行うためにシーンの 仮想光源を設定する。また（f）放射輝度パラメー夕と基礎 画像・拡散反射成分の線形和を GPU で計算し, 影画像を 生成するそそして $(\mathrm{g})$ 影画像を影付け平面にマッピングす る. 最後に (h) 仮想物体と影付け平面を含むシーンをレン ダリングし，実画像と合成する.

\section{3. 提 案 手 法}

本節では，本稿で提案する影付け手法の概要と利点につ いて説明する。 また，影付け平面の生成方法扔よび基礎画 像の合成と，影付け平面へのテクスチャマッピングによっ て影を表現する方法について述べる。

\section{1 提案する影付け手法の利点}

本稿で提案する影付け平面とは，3次元モデルの表面上 に配置した平面状の仮想物体である。この平面群に影の画 像をマッピングし，物体表面とアルファブレンドすること によって，実・仮想物体が相互に投げかけ合う影を表現す る. 影付け平面は仮想物体自身のセルフシャドウ, 仮想物体 が実物体に落とす影，仮想物体が実物体から受ける影，の 3 種類の影を表現することが可能である.

提案手法は従来の影付け手法と比較して, ソフトシャド ウを影画像のマッピングによって，高速に生成できるとい う利点がある. また影付け平面は $3 \mathrm{D}$ モデルの微小な形状 差異を 1 枚の半面内に含み, ユーザの視点からは見えない モデル凹部の影を省略することができる．さらにユーザか らの見え方に応じて遠景・近景のモデルに適応的に配置す ることができる。なお，影付け平面はシーンの幾何形状に 対して前処理段階で配置するため，モデルの移動・変形を 伴わない静的なシーンにのみ適用可能である.

MRに扔ける影の精度を評価する方法としては，実遮蔽 物体と仮想遮蔽物体によって生じる影の誤差を比較する方 


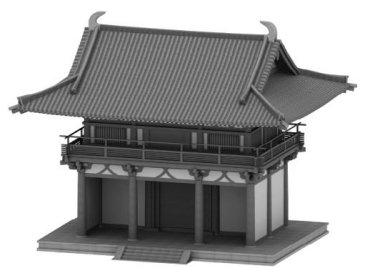

(a) 3Dモデル

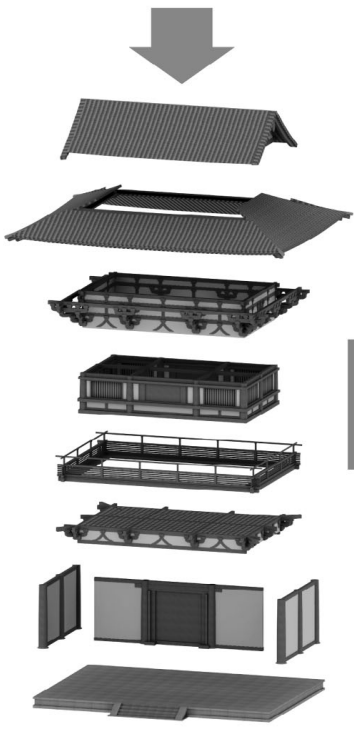

(b) モデルの分割

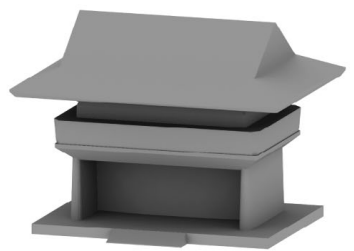

（d）影付け平面

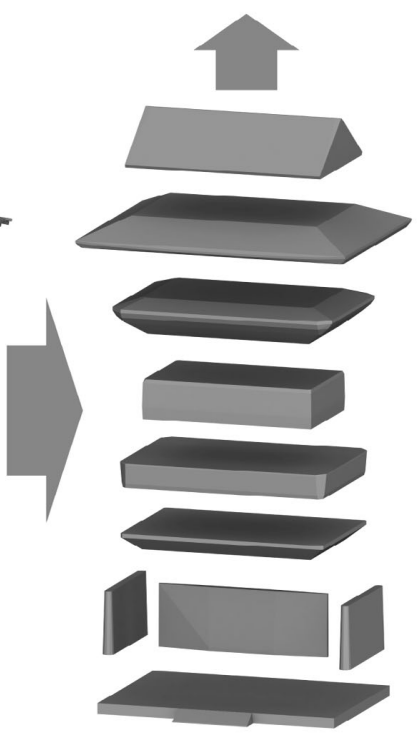

(c) 凸包の生成
図 3 影付け平面の生成 Generation of shadowing planes.

法 ${ }^{14)}$ があるが，実際のアプリケーションではユーザが経験 する主観的な現実感が重要である．そこで提案手法の有効 性を確かめるため，ユーザによる合成画像の主観評価実験 を行った．実験結果については 5.3 節で述べる.

\section{2 影付け平面の生成}

影付け平面は実・仮想物体の幾何モデルから生成する. 実 世界の 3 次元幾何形状を取得するには, 手作業によるモデ リングや，レンジセンサを用いた 3 次元モデルの自動生成 手法 18)19) 等を利用する. 影付け平面を物体の凸包から生 成することによって，物体表面の凹凸を少ないポリゴン数 で近似的に表現することができる.

提案手法では, 図 3 (b) に示すように $3 \mathrm{D}$ モデルを任意 の部分に分割し, 分割後の各部分から凸包を生成する（図 3 (c)）。モデルの分割は凸包が物体表面となるべく一致す るように, ユーザが手作業で行うものとする. 次に各部分 の凸包から面積の大きい主要な面を抽出し, これを影付け 平面として用いる. コーナ部分の微小な山面等は, ユーザ 視点からの可視性を考慮して適宜除外する. 以上の手順に よって任意の数の影付け平面を生成することができる.

\section{3 影付け平面と物体表面のオフセット距離}

物体表面に落ちる影を正確に表現するために，影付け平 面は物体表面の近傍に配置する。ただし図 4 に示すように,

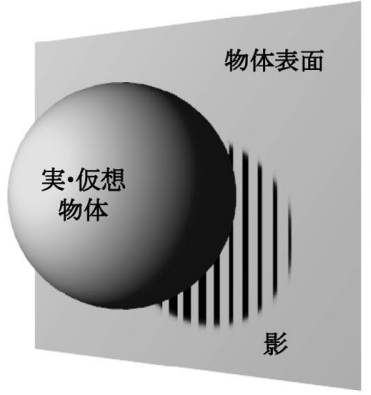

Z-fighting

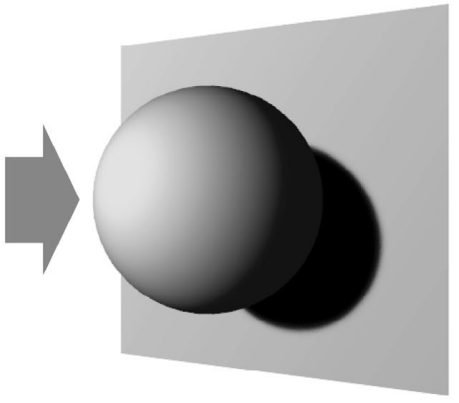

ポリゴンオフセット
図 4 物体表面に対する影付け平面のオフセット配置 Offset of shadowing plane.

物体表面との Z-fighting（複数の面の Z バッファ深度が近 接しているために隠面消去が正確に行われず，表示上のち らつきが生じる問題) を避けるため, システムの Z バッファ のビット数に応じて影付け平面を視点方向に適切な距離だ けオフセットする必要がある. OpenGL では, Z 軸負方向 を向いたカメラの near クリップ平面を $n$, far クリップ平 面を $f$, 物体の $\mathrm{Z}$ 座標を $Z_{o b j}$ とすると, 射影変換後の正 規化装置座標における $\mathrm{Z}$ 座標 $Z_{n d c}$ は以下の式で表される.

$$
Z_{n d c}=\frac{2 f n}{(f-n) Z_{o b j}}+\frac{f+n}{f-n}
$$

さらに near クリップ平面の深度值が 0 , far クリップ平 面の深度值が 1 となるようにビューポート変換を行うと， $Z_{o b j}$ に対応する深度值 $d$ は以下のように求められる.

$$
\begin{aligned}
d & =\frac{Z_{n d c}+1}{2} \\
& =\frac{2 f n}{(f-n) Z_{o b j}}+\frac{f+n}{2(f-n)}+\frac{1}{2}
\end{aligned}
$$

式 3 によってカメラと物体表面との距離に対応した深度 值を求め, 深度值に差異を生む動作環境固有の最小距離を オフセットすることによって，物体表面に対する影付け平 面の最適な位置を決定することができる。なお OpenGL で は glPolygonOffset 関数を使用することによって以上の処 理を行うことが可能である.

\section{4 アルファブレンディングによる影付け}

実・仮想物体表面上のある点における放射照度を $E$ とす

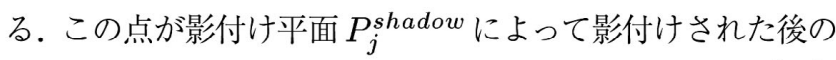
放射照度を $E^{\prime}$ とする. $E^{\prime}$ は基礎画像の合成画像 $\sum I_{j}^{\text {basis }}$ と拡散反射成分の合成值 $\sum d_{j}^{b a s i s}$ を用いて以下のように表 される ${ }^{10)}$.

$$
E^{\prime}=E \frac{\sum I_{j}^{\text {basis }}}{\sum d_{j}^{\text {basis }}}
$$

本手法で提案する影付け平面とのアルファブレンディン グによる影付けを実現するため，影の強度を表す影画像

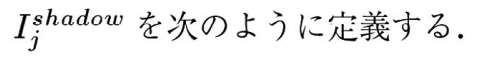

$$
I_{j}^{\text {shadow }}=1-\frac{\sum I_{j}^{\text {basis }}}{\sum d_{j}^{\text {basis }}}
$$




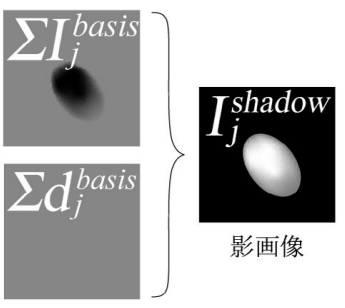

(a) 影画像の生成

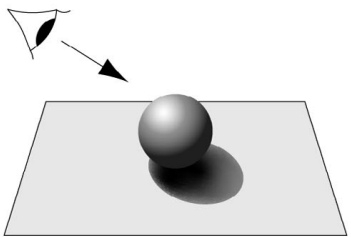

(c) 合成画像

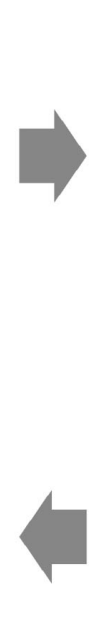

図 5 影画像の作成と影付け平面へのマッピング Generation of shadow images and mapping onto shadowing planes.

式 5 において, 影画像 $I_{j}^{\text {shadow }}$ の中の強度 1 となる画素 は本影（完全に物体に遮られた影）となる部分を示し, 強 度 0 となる画素はまったく影の落ちない部分を示す（図 5 (a)).

本研究では図 5 （b）に示すように, 影付け平面 $P_{j}^{\text {shadow }}$

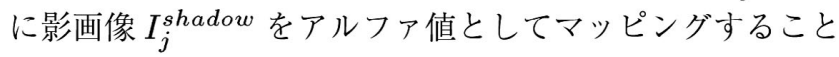
により，物体表面上における影を表現する。ここで影付け 平面は反射率 0 の物体とする，影付け平面と物体表面のア ルファブレンディングを行うことにより，物体表面の放射 照度 $E^{\prime}$ は以下の式で表される。

$$
E^{\prime}=E\left(1-I_{j}^{\text {shadow }}\right)+P_{j}^{\text {shadow }} I_{j}^{\text {shadow }}
$$

式 6 において, 影付け平面 $P_{j}^{\text {shadow }}$ の反射率は 0 と仮定 したため, $P_{j}^{\text {shadow }} I_{j}^{\text {shadow }}=0$ となる.すなわち,

$$
E^{\prime}=E\left(1-I_{j}^{\text {shadow }}\right)
$$

式 7 に式 5 を代入することにより式 4 が得られる。つま り影付け平面に覆われた物体表面の放射照度は影画像の強 度によって減衰し, 他の物体による影付けの影響を表現す ることができる。

最後に，実画像を背景とした状態で仮想物体と影付け平 面を含むシーンのレンダリングを行ない，合成画像を生成 する．影付け平面は仮想物体と実物体のどちらを覆う場合 でも，画素值を減衰させることにより影を表現することが 可能である.

\subsection{GPU による基礎画像の合成}

物体に対して $m$ 枚の影付け平面を生成したとして，各々 の影付け平面を $P_{j}^{\text {shadow }}\{j=1,2, \ldots, m\}$ と表す.また $n$ 個の基礎光源 $L_{i}\{i=1,2, \ldots, n\}$ によって影付け平面 $P_{j}^{\text {shadow }}$ 上に落ちる影を基礎画像 $I_{j, i}^{\text {basis }}$ として表す. 同様 に各々の基礎光源で照射した時に影付け平面 $P_{j}^{\text {shadow 表面 }}$ 上で観測される拡散反射成分を $d_{j, i}^{b a s i s}$ と表す.さらに，あ

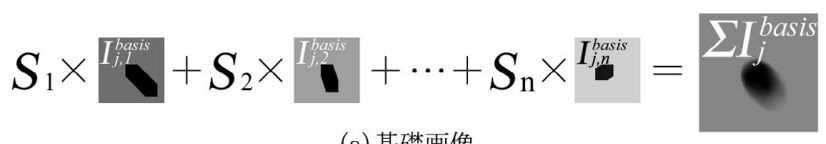

(a) 基礎画像

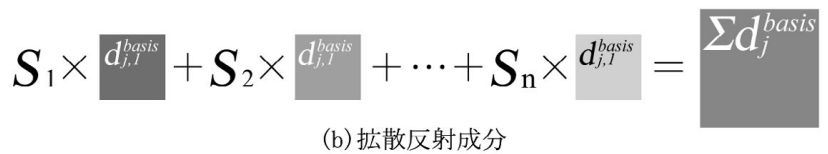

図 6 放射輝度パラメータと基礎画像および拡散反射成分の線 形結合

Linear combination of luminance parameters and basis images and diffuse components.

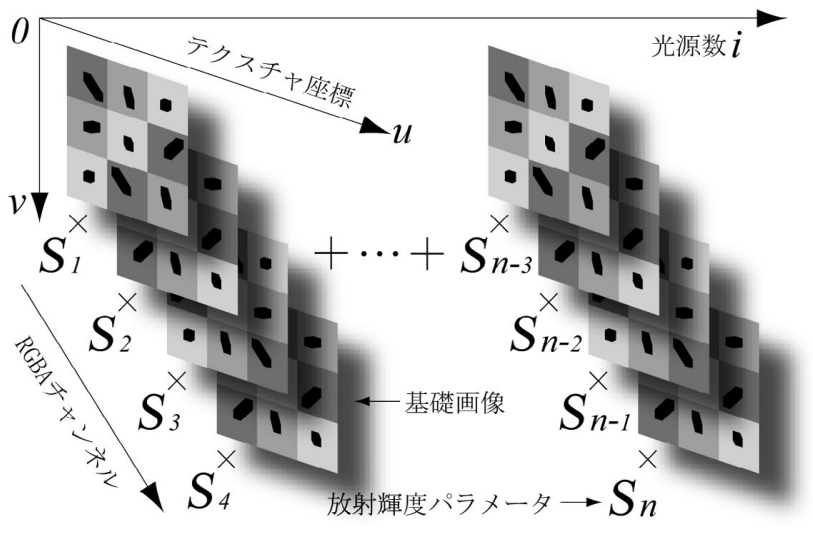

図 7 フラグメントシェーダによる基礎画像の合成 Synthesis of basis images using fragment shader.

る時刻における実光源環境の放射輝度分布を放射輝度パラ メータ $S_{i}$ を用いて表す。

基礎光源の放射輝度と物体表面の放射照度は線形的な関 係にある。この線形性は物体間の相互反射や影についても 同様に成り立つ。そこで図 6 (a) に示すように，影付け平

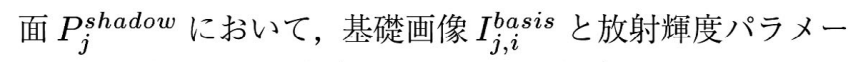
夕 $S_{i}$ の線形結合を行うことにより，任意の光源環境に対 応したソフトシャドウ画像 $\sum I_{j}^{\text {basis }}$ を生成する. また図 6 （b）に示すように，放射輝度パラメータと影付け平面の拡 散反射成分 $d_{j, i}^{\text {basis }}$ の線形和 $\sum d_{j}^{\text {basis }}$ を計算する. 以上の 処理は画像同士の演算であるため, 通常の影付け処理に比 べて高速に実行することができる，また，単純な線形演算 であるため，ハードウェアで処理することができる.

図 7 に GPU のフラグメントシェーダにおけりる基礎画像 の合成方法を示す．フラグメントシェーダでは，頂点をラ スタライズされたフラグメントに対して，テクスチャの合 成が行われる。ここではまず，同一の基礎光源 $L_{i}$ から生成 した基礎画像をタイル状に敷き詰めたテクスチャ岫像を作 成する.テクスチャ画像には影付け平面数 $m$ 枚の基礎画像 が配置される．次に，テクスチャ画像と影付け平面拡散反 射成分 $d_{j, i}^{\text {basis }}$ および放射輝度パラメータ $S_{i}$ をフラグメン トシェーダに転送し, 複数のテクスチャュニットを利用し て線形和を計算する，最後に，合成後のテクスチャ画像に 対して, 元の基礎画像に対応する UV 座標から画素值を抽 出し，影付け平面にマッピングする. 


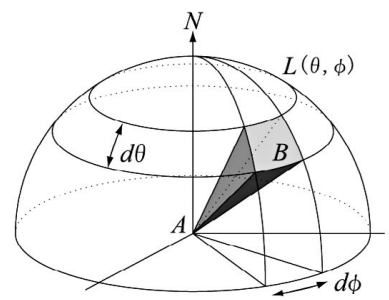

図 8 半球状面光源 Hemispheric surface light source.

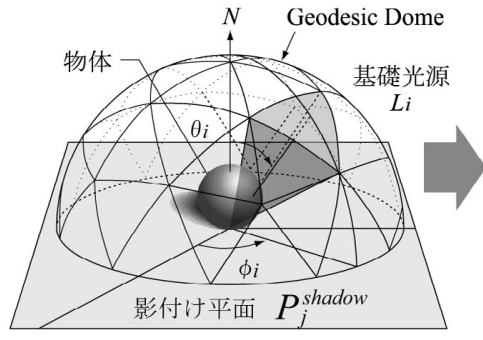

(a) 基礎光源によるレンダリング

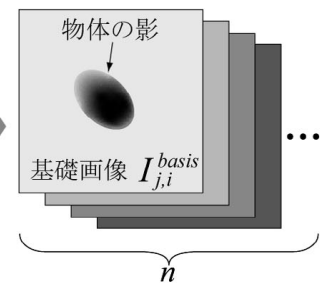

(b) 基礎画像の生成
図 9 基礎画像の生成

Generation of basis images.

\section{4. 実 装}

本章では前処理における基礎光源および基礎光源を用い た基礎画像の生成方法について述べる。

\section{1 基礎光源による実光源環境の近似}

図 8 において，物体表面上の微小面 $A$ における放射照 度を考える。微小面 $A$ に入射するすべての放射束を考える ため，微小面 $A$ から天頂角 $\theta$, 方位角 $\phi$ の方向を見たとき の放射輝度が $L(\theta, \phi)$ であるような半球状の面光源を仮定 する。微小面 $A$ から $(\theta, \phi)$ 方向に微小角度 $(d \theta, d \phi)$ によっ て構成される面光源上の微小領域 $B$ を考えると, 微小面 $A$ が半球状面光源全体から受ける総放射照度 $E$ は次式で表さ れる ${ }^{20)}$.

$$
E=\int_{-\pi}^{\pi} \int_{0}^{\frac{\pi}{2}} L(\theta, \phi) \sin \theta \cos \theta d \theta d \phi
$$

これまでに，球面調和関数などを用いた基礎光源によっ て，任意の光源環境を表現する研究が行われている ${ }^{21)}$ 。し かし従来手法では屋外環境における太陽のような高周波成 分を持つ光源を再現することが困難である．そこで本研究 では, Geodesic Dome を用いて半球状面光源を分割し, 離 散的な基礎光源を生成する。基礎光源の放射輝度スケール を変化させることによって，実世界における任意の放射輝 度分布に対応することが可能となる。

Geodesic Dome とは，各面が 3 角形で構成される正多 面体で，各頂点が球に内接するものであり，球面をほぼ等 しい面積に分割する性質を持つ 22) 23)。図 9 (a) に示すよ うに, Geodesic Domeの各領域によって分割された面光源 を基礎光源 $L_{i}$ とする．半球面の分割が充分に細かく，分割 後の面光源（基礎光源）内の放射輝度が均等であると仮定

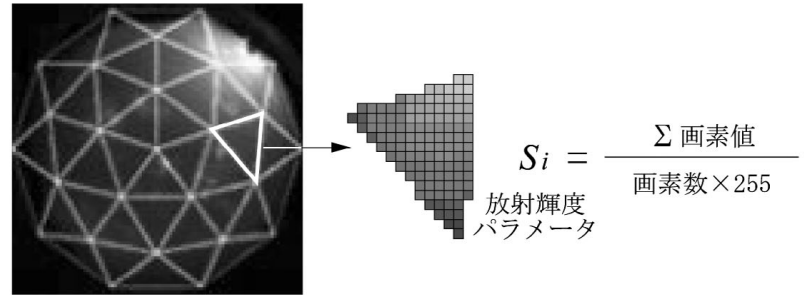

図 10 全方位画像による実世界光源分布推定 Estimation of light distribution from omnidirectional image.

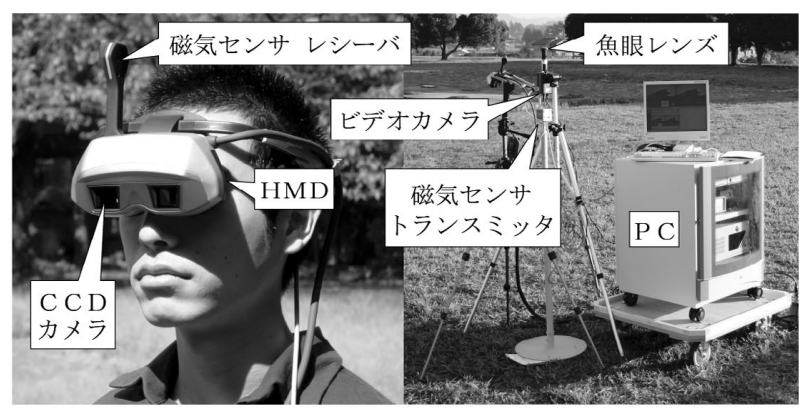

図 $11 \mathrm{MR}$ システムの外観

Apparance of MR-system.

すると, 物体表面上の微小面 $A$ における総放射照度 $E$ は 基礎光源 $L_{i}$ の放射輝度の和によって表すことができる.

\section{2 基礎画像の生成}

図 9 に基礎画像の生成方法を示す。地平面に配置した影 付け平面 $P_{j}^{\text {shadow }}$ に刘し, Geodesic Dome 上の基礎光源 $L_{i}$ によって照射したときに落ちる物体の影を，基礎画像 $I_{j, i}^{b a s i s}$ として取得する。 また，物体を除いた状態で同様に レンダリングを行い, 影付け平面の拡散反射成分 $d_{j, i}^{b a s i s}$ 取得する。

\section{3 実光源環境の取得}

まずカメラを用いて実世界の光源環境を計測し，図 10 に 示すようなすべての光源入射方向に対応する全方位画像を 取得する。次に，全方位画像に Geodesic Dome を投影し， 画像を各々の基礎光源 $L_{i}$ に対応する三角形領域に分割す る.さらに各領域内の画素值の和を求め, これを領域内の 画素值の最大值（255）の和で割ることによって，0.0 1.0 の範囲に正規化された対象領域の放射輝度パラメー夕 $S_{i}$ を 計算する。そしてシーン内の基礎光源に放射輝度パラメー 夕の值を反映させることによって実世界の光源分布を再現 し，仮想物体のシェーディングを行う。また同時に放射輝 度パラメータを 3.5 節で述べた基礎画像の線形結合に用い ることによって，任意の光源分布に対忍した影画像を合成 し，影付け平面を用いて物体の影付けを行う.

\section{5. 実画像との合成実験}

提案手法の有効性を確認するため, 室内・屋外環境におい て実画像に仮想物体を合成し，仮想物体の陰影を表現する 実験を行った。本章ではまず実験に用いた MR システムに ついて説明する。次に室内および屋外での実験結果につい 
て説明する。なお本稿では計算効率を高めるため, 基礎画 像をグレースケール画像として保存し, GPUのテクスチャ RGBA チャネルにそれぞれ異なる基礎画像を割当てた. そ のため光源と影の色は考慮しないものとする.

\subsection{MR システム}

基本となる MR システムには，キヤノン社の MR Platform $^{24)}$ を用いた. MR Platform はビデオシースルー方式 の HMD, Polhemus 社の 6 自由度磁気センサFASTRAK によって構成される.このシステムでは, 実画像の取得, 実 世界と仮想物体の幾何学的位置合わせ，実画像と仮想物体 の合成処理を行うことができる，HMD 上に表示される合 成画像の大きさは $640 \times 480$ 画素である. 実光源環境の撮影 には魚眼レンズ（FIT 社 FI-19）を装着した CCD カメラ （Victor 社 KY-57）を使用した。実験に用いた PC の仕様 は, OS: Windows XP (SP2), CPU: Core2Duo E6850 3.0GHz, RAM: 4GB, GPU: nVIDIA GeForce8800GTS 640MB である.MR システムの外観を図 11 に示す.

\section{2 実験結果（室内環境）}

室内環境における実画像との合成結果を図 12 に示す。影 付け平面は地面に対して 1 枚設置し，40 個の基礎光源を用 いて $128 \times 128$ 画素の基礎画像 40 枚を生成した. 図 12 (a) では仮想物体の院影を全く表現していないため，不自然な 合成画像になっている. 次に図 12 (b) では仮想物体の表 面におけるシェーディングを表現している．仮想物体の立 体感が追加されたが, 実画像の地面からは浮いているよう に見える。ささに図 12 (c) では影付け平面を用いて地面 に落ちる仮想物体の影を表現している．仮想物体の違和感 が解消され，より自然な合成画像が生成されている.さら に図 12 (d) に示すように，ユーザ視点を移動した場合で も, 影付け平面によって正しい位置に影が表現されている. なお本実験では，仮想物体表示位置の地面において光源環 境の撮影を行った. また仮想物体のポリゴン数は 12 であ る.ディスプレイとの垂直同期を有効にした場合，陰影処 理を含めた描画フレームレートはディスプレイの垂直同期 周波数と一致した. 重直同期を無効にした場合，1フレー ムあたりの処理速度は 0.93 ミリ秒であった。

\section{3 実験結果（屋外環境）}

屋外環境における実画像との合成結果を図 13 に示す. 図 13 （a）は仮想物体のシェーデイングは行っているが, 影付 けは行っていない画像, 図 $13(\mathrm{~b})$ は仮想物体のシェーディ ングと影付けを行っている画像である。ここでは 36 枚の影 付け半面と 40 個の基礎光源を用い, 合計 1520 枚の基礎丰 像を生成した。

実験環境は周囲に建物等が存在しない平地である. 光源 環境の撮影はユーザや機材等が映り込まないように, MR システムから約 $5 \mathrm{~m}$ 離して行った. また仮想物体のポリゴン 数は約 50000 である.ディスプレイとの垂直同期を有効に した場合，陰影処理を含めた描画フレームレートはディス プレイの垂直同期周波数と一致した。垂直同期を無効にし
た場合，1フレームあたりの処理速度は 1.46 ミリ秒であっ た。なお図 13 (b) において，36枚の影付け平面のうちカ メラの視野に含まれない 21 枚の描画を省略した場合，1 レームあたりの処理速度は 1.29 ミリ秒となり約 $13 \%$ の向 上が確認された。

影付けによる現実感の向上を確認するために, 屋外環境 における合成画像を用いて，ユーザによる主観評価を行っ た、VR・MRにおける CGの影の有無と誤差がユーザに与 える影響を評価した事例としては, ${ }^{25) 26)}$ が挙げられる。本 稿では $23 \sim 33$ 歳の大学院生 13 名に合成画像を呈示し, 影 がある場合とない場合では，画像から受ける現実感がどの 程度変化するかを調査した。評価方法は, 図 13 の仮想物 体を様々な視点から見た, 影の有無を含む合成曲像 19 枚を ランダムに呈示し, 各画像から受ける印象について, 調査 用紙に 7 段階 (1: 非常に不自然〜 7 : 非常に自然) で評価し てもらった．影の有無で分けた画像グループごとの平均值 を図 13 (c) に示す。影付けによって見た目の現実感は約 $22 \%$ 向上しており, 提案手法の有効性を確認することがで きた.

\section{6. むす び}

本稿では，影付け平面と基礎画像を用いた MRにおける 高速陰影表現手法を提案した。この手法は従来手法に比べ て，1）影付け平面を用いたモデルベース手法のため, 視点 の移動が可能，2）GPUによる処理の高速化が可能，とい う新規性がある。提案手法では前処理の段階で, 影を受け る物体の表面上に影付け平面を設置し, 実光源環境を近似 した基礎光源により，各々の影付け平面に落ちる仮想物体 の影を基礎画像として取得する，逐次処理の段階では，ま ず魚眼レンズ付ビデオカメラにより実光源環境の全方位画 像を撮影し，分布を表す放射輝度パラメータを求める. 次 に放射輝度パラメータを元に仮想物体のシェーディングを 行い，基礎画像の線形和を求める．最後に合成後の基礎画 像と影付け平面の拡散反射成分から影画像を生成し, 影付 け平面にアルファ值としてマッピングすることにより，ソ フトシャドウを表現する。また Geodesic Domeを用いた 光源分布推定では，実環境光源の複雑な配光特性を正確に 取得することは困難である. 光源推定手法を改良し，複雑 で規模の大きい仮想物体に対しても，実物体の影を正確に 表垷することが, 今後の課題として挙げられる.

本研究の一部は, 文部科学省技術振興調整費リーディン グプロジェクト「大型有形・無形文化財の高精度デジタル 化ソフトウェアの開発」の援助を受けて行った。また，実 験の場を与えて下さった明日香村役場, 復元図面をご提供 いただいた橿原考古学研究所, 奈良文化財研究所, 論文の 構成についてご助言をいただいた東京大学生産技術研究所 の高松淳氏に感謝の意を表する。

(161) 793 


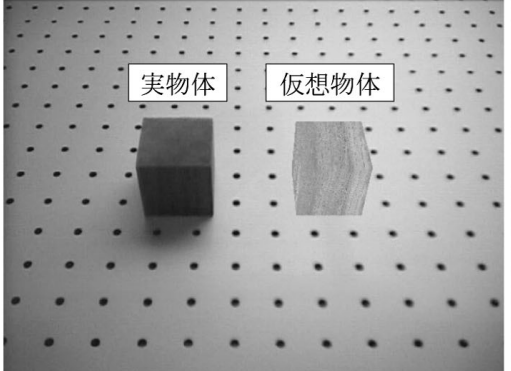

(a) 仮想物体の合成
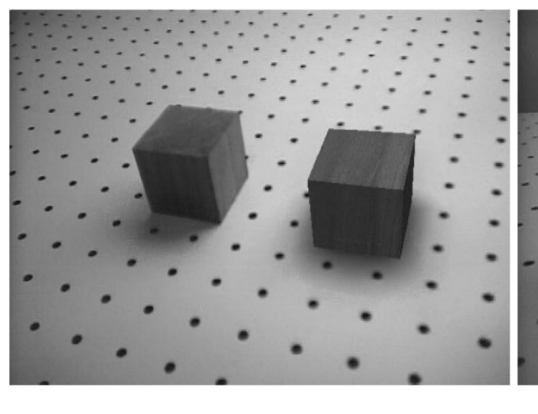

図 12 仮想物体の陰影付けの比較（室内）

Comparison of shading and shadowing of virtual object indoors.

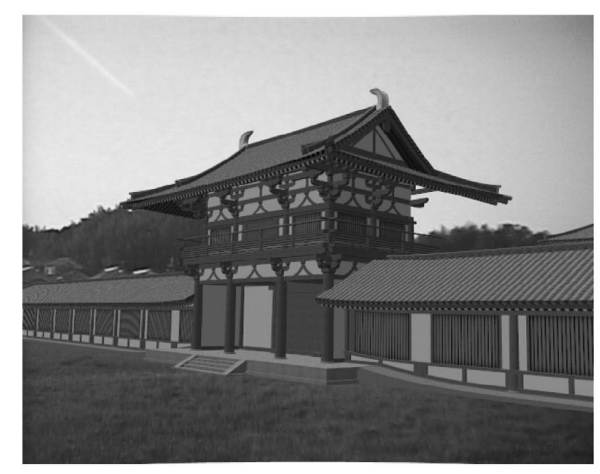

(a) 合成画像 (仮想物体の影付けなし)

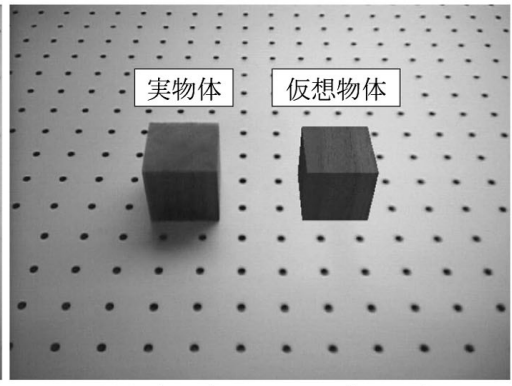

(b) 仮想物体のシェーディング

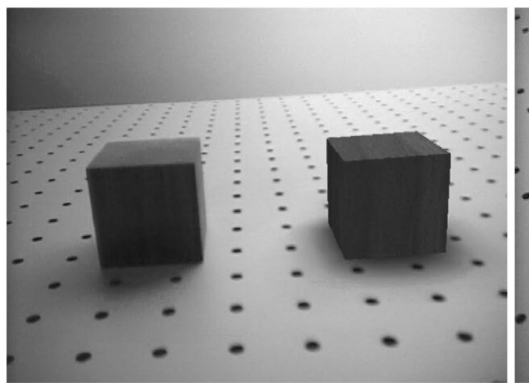

(d) ユーザの視点変更に対応

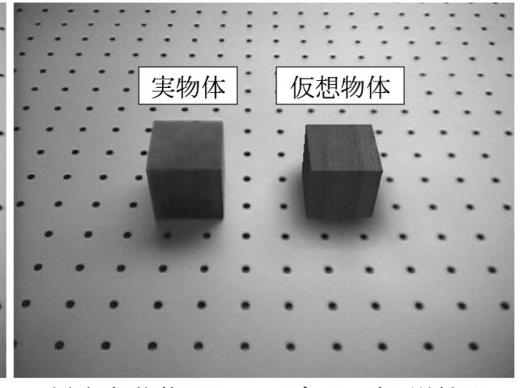

(c) 仮想物体のシェーディングと影付け

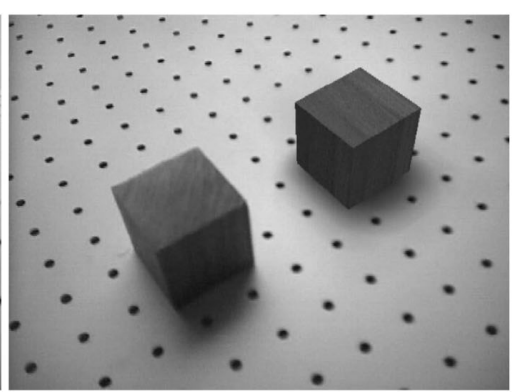

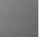

\section{(n)

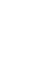

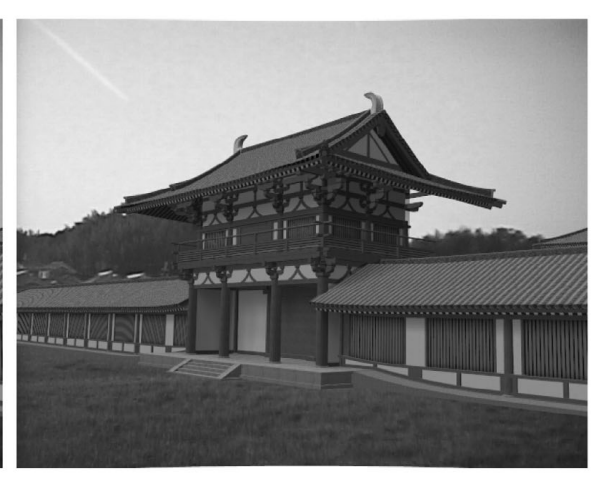

(b) 合成画像 (仮想物体の影付けあり)

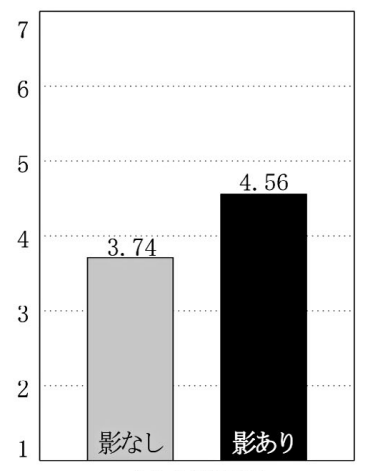

(c) 主観評価

园 13 仮想物体の陰影付けの比較（屋外）

Comparison of shading and shadowing of virtual object outdoors.

\section{〔文献〕}

1）田村秀行, 大田友一：“複合現実感”, 映情学誌，52，3，pp.266-272 (March 1997)

2) R. Azuma:"A Survey of Augmented Reality”, Presence: Teleoperators and Virtual Environments, 6, 4, pp.355-385 (August 1997)

3) R. Azuma, Y. Baillot, R. Behringer, S. Feiner, S. Julier, and B. MacIntyre:"Recent Advances in Augmented Reality", IEEE Computer Graphics and Applications, 21, 6, pp.34-47 (November 2001)

4）池内克史, 佐藤洋一, 西野恒, 佐藤いまり : “複合現実感における光学的 整合性の実現”，日本バーチャルリアリティ学論誌，4，4，pp.623-630 (December 1999)

5) A. Woo, P. Poulin, and A. Fournier :"A Survey of Shadow Algorithms", IEEE Computer Graphics and Applications, 10, 6, pp.13-32 (November 1990)

6) F. Crow:"Shadow Algorithms for Computer Graphics", Proc. SIGGRAPH'77, pp.212-218 (1977)

7) J. M. Hasenfratz, M. Lapierre, N. Holzschuch, and F.X. Sillion: "A Survey of Real-time Soft Shadows Algorithms", Computer Graphics Forum, pp.753-774 (December 2003)

8) K. Jacobs and C. Loscos:" Classification of Illumination Methods for Mixed Reality", Proc. Eurographics State of the Art Report(STAR), pp.95-118 (September 2004)

9）佐藤いまり, 林田守広, 甲裴郁代, 佐藤洋一, 池内克史: “実光源環境 下での画像生成：基礎画像の線形和による高速レンダリング手法”，信
学論 (D-II), J-84-D-II, 8, 1234-1242, (August 2001)

10) I. Sato, Y. Sato, and K. Ikeuchi:"Acquiring a Radiance Distribution to Superimpose Virtual Objects onto a Real Scene", IEEE Trans. on Visualization and Computer Graphics, 5, 1, pp.1-12 (January-March 1999)

11) P. Debevec: "Rendering Synthetic Objects into Real Scenes: Bridging Traditional and Image-Based Graphics with Global Ilumination and High Dynamic Range Photography", Proc. SIGGRAPII '98, pp.189-198, (July 1998)

12) M. Kanbara and N. Yokoya: "Geometric and photometric registration for real-time augmented reality", Proc. Int. Symp. on Mixed and Augmented Reality (ISMAR02), pp.279-280 (September 2002)

13) H. Matsuoka, A. Onozawa and E. Hosoya:"Environment Mapping for Objects in the Real World: a Trial Using ARToolkit", Proc. Int. Augmented Reality Toolkit Workshop (September 2002)

14) I. Sato, Y. Sato, and K. Ikeuchi:"Illumination from Shadows", IEEE Trans. on Pattern Analysis and Machine Intelligence, 25, 3, pp.290-300 (March 2003)

15) M. Haller, S. Drab, and W. Hartmann :“A Real-Time Shadow Approach for an Augmented Reality Application Using Shadow Volumes", Proc. Symp. on ACM Virtual Reality Software and Technology(VRST'03), pp.56-65 (October 2003)

16）神原誠之, 岩尾友秀, 横矢直和 :“拡張現実感のための動的シャドウマッ プを用いたシャドウレンダリング手法”，画像の認識・理解シンポジウ ム (MIRU2005), pp.297-304 (July 2005)

17) J. S. Nimeroff, E. Simoncelli, and J. Dorsey: "Efficient Re- 
Rendering of Naturally Illuminated Environments”, Proc. Eurographics Workshop on Rendering (EGWR94), pp.359-373 (June 1994)

18) M. Levoy, K. Pulli, B. Curless, S. Rusinkiewicz, D. Koller, L. Pereira, M. Ginzton, S. Anderson, J. Davis, J. Ginsberg, J. Shade, and D. Fulk:"The Digital Michelangelo Project: 3D Scanning of Large Statues", Proc. SIGGRAPH'00, pp.131-144 (July 2000)

19) K. Ikeuchi :"Modeling from Reality”, Proc. Third International Conference on 3D Digital Imaging and Modeling (3DIM'01), pp.177 (May 2001)

20) B. K. P. Horn :"Robot Vision”, The MIT Press (March 1986)

21) P. P. Sloan, J. Kautz, J. Snyder:"Precomputed Radiance Transfer for Real-Time Rendering in Dynamic, Low-Frequency Lighting Environments", Proc. SIGGRAPH'02, pp.527-536 (July 2002)

22) A. Pugh:"Polyhedra: a Visual Approach", University of California Press (September 1976)

23) K. Ikeuchi :"Recognition of 3D Object using the Extended Gaussian Image", Proc. 7th International Joint Conference on Artificial Intelligence, pp.595-600 (August 1981)

24) S. Uchiyama, K. Takemoto, K. Satoh, H. Yamamoto, and H. Tamura:"MR Platform: A Basic Body on Which Mixed Reality Applications Are Built”, Proc. Int. Symp. on Mixed and Augmented Reality (ISMAR02), pp.246-253 (September 2002)

25）中村宣孝, 宮里勉，岸野文郎:“仮想空間における影の効果に関する評 価”, 信学会 1995 年総合大会講演論文集, pp.263 (March 1995)

26）中野学，北原格，亀田能成，大田友一:“複合現実感における影の不整 合に関する実験的検討”, 信学会 2007 年総合大会講演論文集, pp.169 (March 2007)

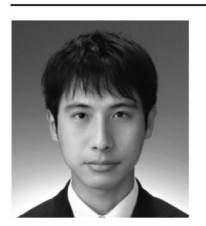

角笛哲也 2002 年, 京都大学工学部建筑学科卒 業. 2005 年, 東京大学大学院学際情報学府学際情報学専 攻修士課程終了. 現在, 同大大学院学際情報学府学際情 報学専攻博士課程在籍. 日本学術振興会特別研究員 DC. 複合現実感の研究に従事.

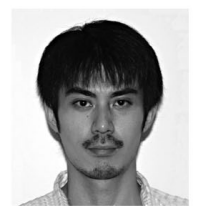

大势热岳史 1999 年慶應義塾大学理工学部電気工 学科卒業. 2002 年東京人学人学院学際情報学府学際情報 学専攻修士課程修了. 2005 年東京大学大学院学際情報学 府学際情報学専攻博士課程修了. 同年東京大学生産技術 研究所特任助手, 2006 年特任助教を経て, 2007 年より 東京大学大学院情報学環特任講師. 実物体の形状モデリ ングの研究に従事. 博士 (学際情報学).

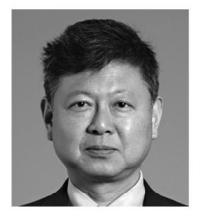

池內 克史 京都大学工学部機械工学科卒業. 1978 年, 東京大学大学院工学系研究科情報工学専攻博士課程 終了. MIT 人工知能研, 電総研, CMU 計算機科学科を 経て，1996 年より，東京大学生産技術研究所教授. 2000 年より, 東京大学大学院情報学環教授兼担. 人間の視覚 機能, 明るさ解析, 物体認識, 人間による組立て作業の 白動認識などの研究に従事. 正会員. 